\title{
The effect of concrete strength and reinforcement on toughness of reinforced concrete beams
}

\author{
J.O. Carneiro ${ }^{\mathrm{a}, *}$, S. Jalali ${ }^{\mathrm{b}}$, V. Teixeira ${ }^{\mathrm{a}}$, M. Tomás ${ }^{\mathrm{b}}$ \\ a Department of Physics. University of Minho, Azurim Campus, PT-4800-058 Guimaräes, Portugal \\ 'Department of Cinil Engineering, Enitersity' of Minhe, Azurem Campus. PT-4800-058 Guimarâs, Portugal
}

Received 28 April 2004; received in revised form 30 September 2004; accepted 26 January 2005

\begin{abstract}
The objective pursued with this work includes the evaluating of the strength and the total energy absorption capacity (toughness) of reinforced concrete bcams using different amounts of stecl-bar reinforcement. The experimental campaign deals with the evaluation of the threshold load prior collapse, ultimate load and deformation, as well as the beam total energy absorption capacity, using a three point bending test. The beam half span displacement was measured using a displacement transducer, and the applied force was monitored using a load ccll. The tested samples consists on a set of ten reinforced concrete beams having three different levels of steel-bar-reinforcement percentages and four different concrete compositions (i.c., giving rise to a different values of concrete strength). It was observed that the most influential parameter in the beams energy absorption capacity is the amount of steel-bar reinforcement. The results have presented good agrement between themselves. In fact, for bcams with a given concrete compressive strength, a decrease in beam's deformation was measured for higher steel-bar-reinforcement percentages. Moreover, the results had shown that for a particular stcel-bar-rcinforcement percentage, the concrete compressive strength have also influence in the total cnergy absorption capacity of the beams.
\end{abstract}

(C) 2005 Elsevier Lid. All rights reserved.

Keyvords: High performance concrete; Concrete strength; Steel-bar-rcinforcement: Beam toughness

\section{Introduction}

Significant progress in mechanical and durability performance of concrete has been achieved through a combination of new chemical admixtures and mineral additions during the last decade, leading to production of High Performance Concretc (HPC). Enormous advantages arise from the utilisation of such (HPC) in structures where demands on strength, durability and real service life are high [1]. Examples of such constructions are long span bridges, struc-

\footnotetext{
"Corresponding author. Tel.: +351 253510477 ; fax: +351 253510 401 .

E-mail address: carneiro@fisica.uminho.pt (J.O. Carneiro).
}

tures in marine environment and oflshore structures [2].

However, the progress does not always bring only advantages. In fact, it is observed that concrete become more brittle and less deformable as its compressive strength increases. This behaviour has become evident from experimental tests carried out on HPC specimens subjected to axial compression. In such tests the occurrence of an extremely explosive rupture is noted. This brittle behaviour of HPC has raised concerns with regards to its real application. In fact, the observed decrease on deformability of HPC need not necessarily result in a deformability decrease of reinforced concrete structural elements, because a rcinforced concrete element combines a brittle HPC with high toughness reinforced bars. 


\section{Previous studies}

Concrete consists of the cement paste that acts as the matrix linking the aggregates. The matrix is porous and usually filled with fluid. Other constituents present are additives and admixtures in order to impart specific properties of the fresh concrete such as higher plasticity, retardation or acceleration of setting lime.

The application of fracture mechanics to concrete involves precautions and the success in its applicability is still investigated. The first experimental study on the applicability of fracture mechanics to concrete was carried out by Kaplan [3] in 1961. Other studies had been followed and nowadays a continuous investigation in this domain is considered of priority $[4,5]$ as it can contribute to production of concrete with increased strength. Morcover, Leslie el al. [6] have studied the influence of the concrete strength and the steel-bar-reinforcement percentage parameters on toughness of HPC. reinloreed beams submitted to a pure bending moment. Subsequent studics, carried out by Tognon ct al. [7], Pastor et al. [8], Shin et al. [9], Ahmad et al. [10] and Lopes et al. [11] have confirmed the influence of the parameters prior enunciated although the results are still scarce and are not completely concordant concerning toughness dependence with those parameters. Hence, there is a need for further research in order to evaluate the effect of concrete strength and stecl-bar-reinforcement percentage on the total energy absorption capacity of concrete beams. In this research work a conventional concrete (45 MPa compressive strength) and a HPC $(90$ and $150 \mathrm{MPa}$ compressive strength) were manufactured and the steel-bar-reinforcement percentage area varied from 0.428 to 1.684 which lie between 0.066 and 8.11 which are the allowable minimum and maximum values indicated by Portuguese building code for specimens using $45 \mathrm{MPa}$ concrete strength.

\section{Experimental work}

\subsection{Concrete mixes tested}

Threc different concretc compositions were selected in order to achieve three different classes of concrete strength, namely B45, B90 and B150. The specimens werc labelled with a prefix $B$ that means beam and the number denotes the concrete strength in MPa. Moreover, a mixture similar to $\mathrm{B} 90$ was used with partial replacement of sand by ground rubber particles, labelled as BB60. The rubber addition to the concrete had the purpose to study the influence of rubber on both concrete strength and deformability.

Cement type $1 \mathrm{I}-42.5$ was used in production of concretes B45 and B90 along with river sand and crushed granitc coarse aggregate with dimensions between / and $10 \mathrm{~mm}$. The water reducing agent Rheobuild 1000 was also used. For B1 50 cement type I - 52.5 R, metakaolin and superplastizer type Glénium C313 were used. The different concrete compositions are summarized in Table 1.

Fig. 1 shows a Scanning Electron Microscopy (SEM) top view micrograph [12] for B45 conventional concrete. It is clearly shown the sand and crushed granite coarse aggregate surrounded by the cement past and the presence of large pores in the concrete mass is also evident.

In order to cvaluate the strength of concretc, three concrete cubes $\left(5 \times 5 \times 5 \mathrm{~cm}^{3}\right)$ were moulded (see Fig. 2(a)). The strength of mixes was obtained, at the same age as the beam, using a hydraulic press (see Fig. 2(b)).

Table I

Concrele compositions

\begin{tabular}{lllll}
\hline Materials & B45 & B90 & B150 & BB60 \\
\hline Cement $\left(\mathrm{kg} / \mathrm{m}^{3}\right)$ & 300 & 360 & 600 & 360 \\
W/C ratio & 0.45 & 0.4 & 0.28 & 0.4 \\
Sand $\left(\mathrm{kg} / \mathrm{m}^{3}\right)$ & 1197 & 1011.4 & - & 767.33 \\
Coarse aggregates $\left(\mathrm{kg} / \mathrm{m}^{3}\right)$ & 712.5 & 776.3 & - & 776.3 \\
Metakalin $\left(\mathrm{kg} / \mathrm{m}^{3}\right)$ & - & 40 & 90 & 40 \\
Super plasticizer $\left(1 / \mathrm{m}^{3}\right)$ & 6 & 7.2 & 75 & 7.2 \\
Rubber $\left(\mathrm{kg} / \mathrm{m}^{3}\right)$ & & - & - & 76.73 \\
Crushed ceramic $\left(\mathrm{kg} / \mathrm{m}^{3}\right)$ & - & - & 1385 & - \\
\hline
\end{tabular}

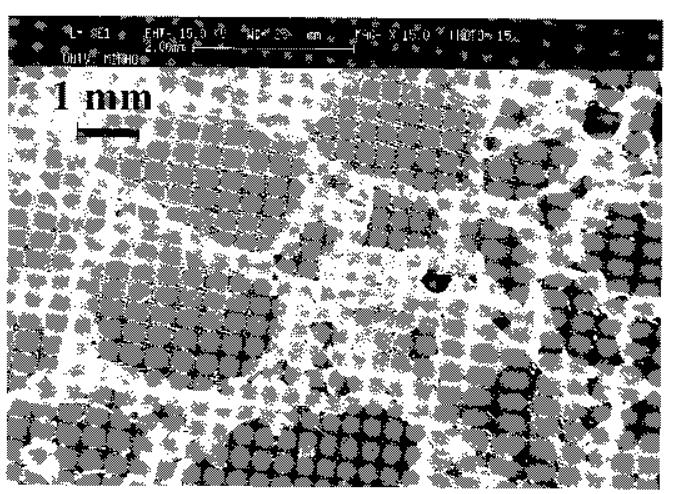

Fig. 1. SEM micrograph showing the surface of the conventional concrete specimen. (a)

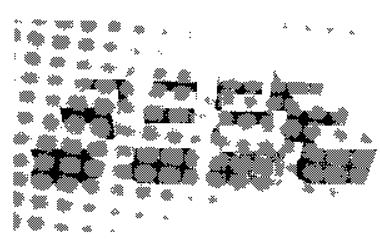

(b)

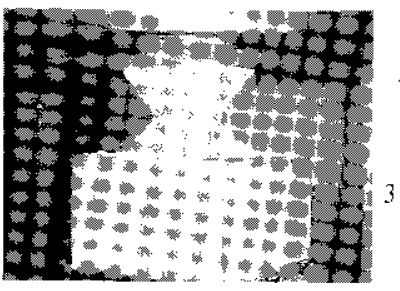

Fig. 2. (a) Cubic concrete specimens, (b) hydraulic press. 


\subsection{Reinforced concrete beams}

In the experimental campaign a set of destructive tests were performed on ten reinforced concrete beams. The beams were cast in the horizontal position using a wood formwork. The casting of the beams was carried out with the reinforcement steel bars properly embedded in the fresh concrete. After 50 days the beams werc removed from the mould, transported to the working testing area and positioned on the testing steel frame. The bcams, simply supported, were submitted to the action of a point force applied on the beams central region. In Fig. 3 are represented schematically the beams and the reinforcement bar configurations.

Table 2 presents the characteristics of each beam: the lotal area of the stecl-bars $A_{\mathrm{s}}$, the steel-bar percentage area (as per cent of beam cross-section area) $\rho$, and the density of concrete $\mu$. Furthermore, it is noted that all beams have square cross-section $\left(h \times b=100 \mathrm{~cm}^{2}\right)$ and the depth of the tension steel from the lop surface of the beam cross-section (i.e., the effective height) is
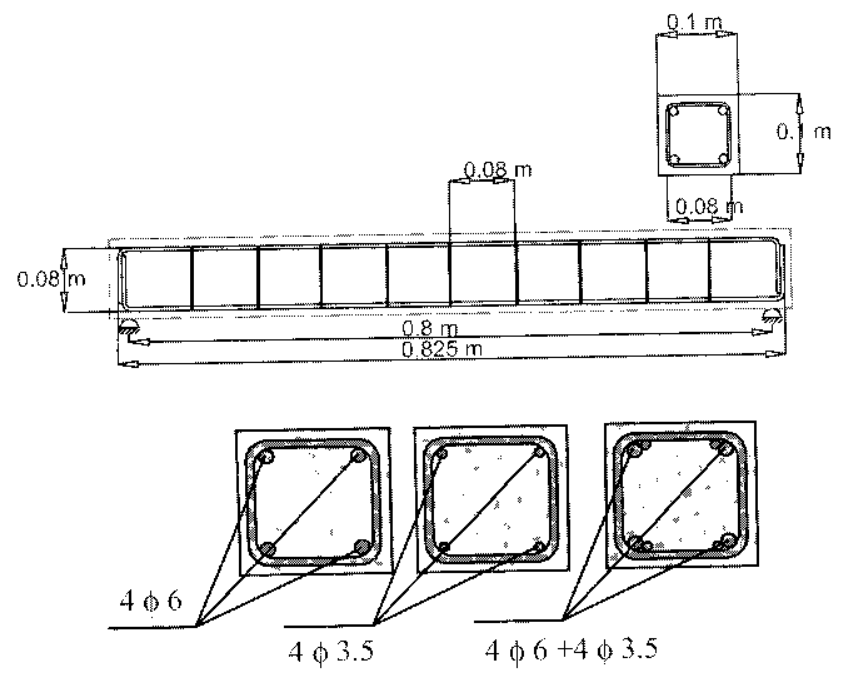

I.ig. 3. Beam geometry and delail for the reinforcement bar configurations.

Table 2

Summary of experimental design

\begin{tabular}{|c|c|c|c|c|}
\hline Series & Group code & $A_{\mathrm{s}}\left(\mathrm{cm}^{2}\right)$ & $\rho(1 / 1)$ & "II $\left(\mathrm{kg} / \mathrm{m}^{3}\right)$ \\
\hline 1 & $\begin{array}{l}1 \mathrm{~B} 45-0.428 \\
1 \mathrm{~B} 45-1.256 \\
1 \mathrm{~B} 45-1.684\end{array}$ & $\begin{array}{l}0.3848 \\
1.131 \\
1.516\end{array}$ & $\begin{array}{l}0.428 \\
1.256 \\
1.684\end{array}$ & 2280 \\
\hline 2 & $\begin{array}{l}2 \mathrm{~B} 90-0.428 \\
2 \mathrm{~B} 90-1.256 \\
2 \mathrm{~B} 90-1.684\end{array}$ & $\begin{array}{l}0.3848 \\
1.131 \\
1.516\end{array}$ & $\begin{array}{l}0.428 \\
1.256 \\
1.684\end{array}$ & 2420 \\
\hline 3 & $\begin{array}{l}3 B 150-0.428 \\
3 B 159-1.256 \\
3 B 150-1.684\end{array}$ & $\begin{array}{l}0.3848 \\
1.131 \\
1.516\end{array}$ & $\begin{array}{l}0.428 \\
1.256 \\
1.684\end{array}$ & 2155 \\
\hline 4 & $4 B B 60-1.256$ & 1.131 & 1.256 & 2340 \\
\hline
\end{tabular}

$d=9 \mathrm{~cm}$. The beams were grouped in four scries as a function of the concrete strength.

Each beam group is labelled by its series, where the first number after the letter $B$ is the concrete compressive strength $f c$, and the last number is the percentage area of the reinforcement stcel-bar. The fourth series (4BB601.256) refers to a beam with rubber addition to the concretc. Fig. 4 shows schematically a beam on its experimental set-up as well as the instrumentation used for the measurement of the results.

\subsection{Concrete compressive strength}

The concrete strength was evaluated by compression tests on specimens cured for 50 days. Fig. 5(a) (c) shows the results of compression tests performed on cubic concrete specimens. Fig. 5(d) refers to the cubic specimen of concrete with rubber addition. The three curves represented in each figure correspond to three experimental tests performed for each concrete mixture. The peak value registered is taken as the strength of the specimen.

Results from concrete $\mathrm{B} 90$ and $\mathrm{B} 150$ indicate a brittle fracture (explosive rupture in the case of B150) with a sharp loss of strength after the peak value. In the case of the concrete B45 specimen, results indicate a higher toughness showing some strength after reaching the peak valuc. Indeed, given that the composition of the BB60 concrete is similar to that of the B90 concrete, it is noted that the addition of rubber causes a loss of strength (some $30 \%$ ), but the loss of strength when peak value is reached is less abrupt.

\subsection{Bending strength of the reinforced concrete beams}

\subsubsection{Experimental results}

Fig. 6(a)-(d) presents the load displacement curves, i.e., behaviour curves, obtained from the experimental measurements of beams submitted to a three point bending test. Each graph refers to a scries of three tested beams (corresponding to each concrete strength values) with increasing levels of the stect-bar reinforcement

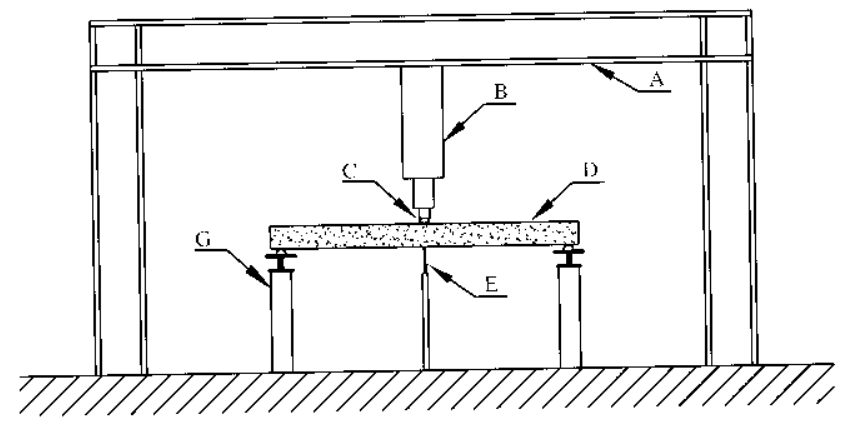

Fig. 4. Three-point loading experimental set-up: (A) steel frame structure. (B) hydratilic actuator. (C) load cell, (D) beam, (E) displacement transducer, (G) metallic support. 

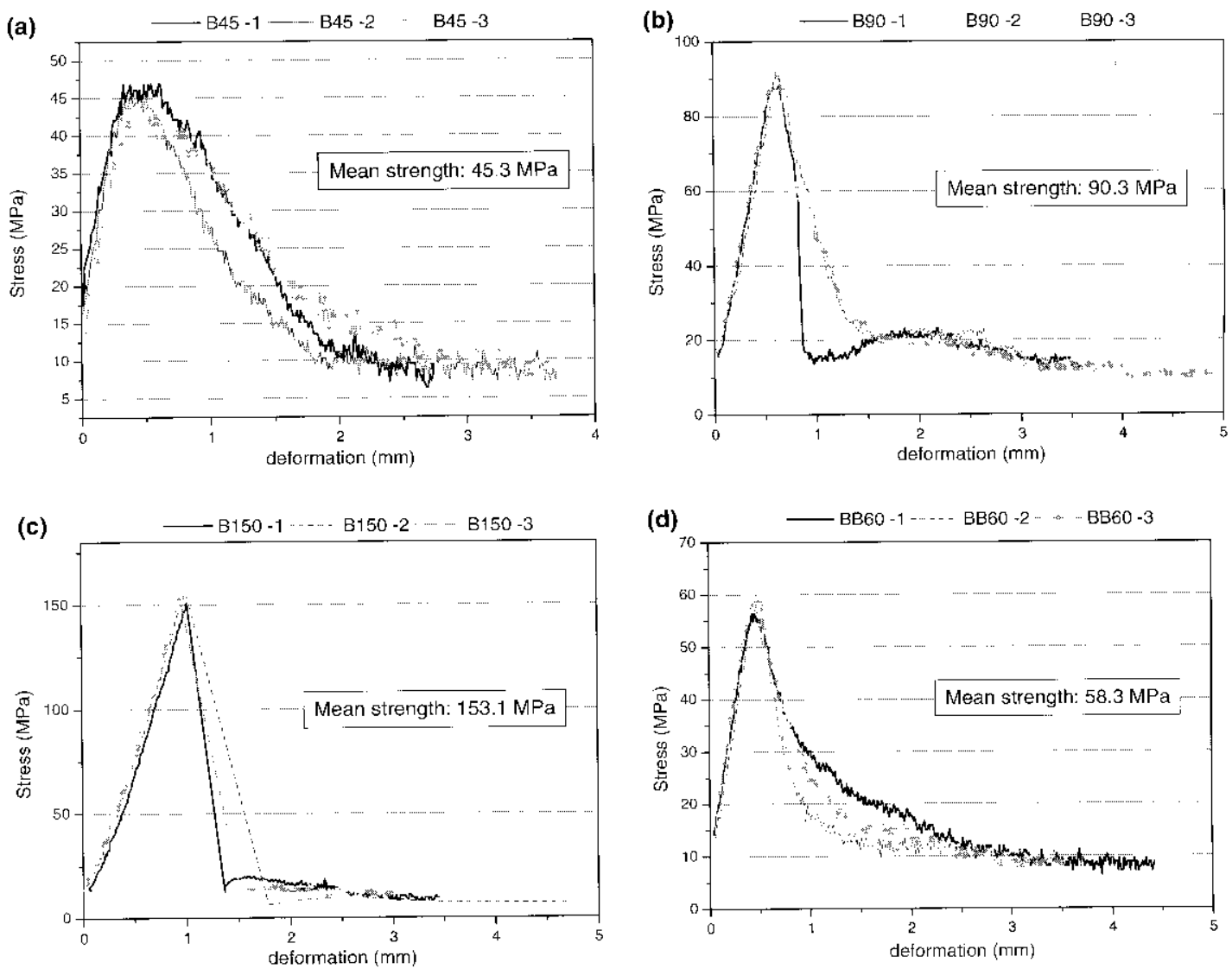

Fig. 5. Experimental results from compressive lests performed on cubic concrete test-specimens: (a) B45 specimen, (b) B90 specimen. (c) B150 specimen, (d) BB60 specimen.
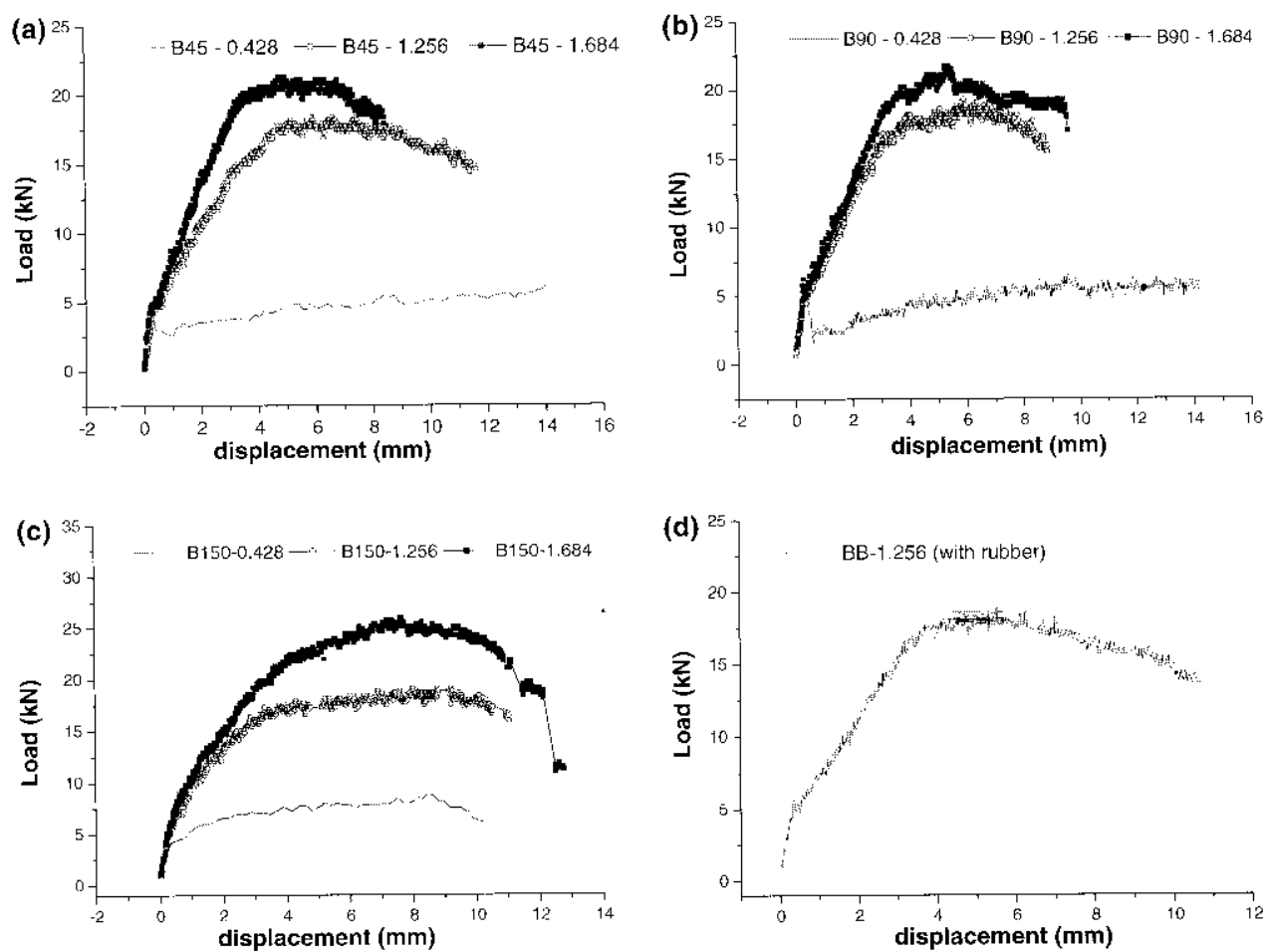

Fig. 6. Experimental beam load displacement curves for different concrete strength values and steel-bar-reinforcement percentage: (a) B45 specimen, (b) 390 specimen. (c) B150 specimen, (d) BB60 specimen. 
percentage. For all series it can be observed that for increased levels of the steel-bar reinforcement, the beam maximum load is also increased. However, in all situations, the beam deflection measurcd at the maximum load (i.e., the beam mid span peak displacement $\delta_{\mathrm{m}}$ ) decreases for higher levels of steel-bar reinforcement. In fact, this is a normal consequence of the revised moment of incrtia, $I_{\text {cracked eflectiv: }}$ the more steel the higher

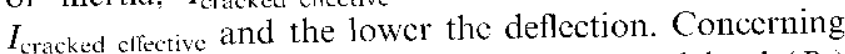
the curve last points, i.e., the last measured load $\left(P_{\mathrm{u}}\right)$ and beam last deflection $\left(\delta_{\mathrm{u}}\right)$ it is observed that for the particular 1.684 steel-bar reinforcement percentage, higher concrete strength valucs leads to an increase of the last beam deflection and a decrease of the last measured load (see Table 3 ). In this case, the higher concreto strength the lower $I_{\text {cracked effective }}$ and the higher the last deflection.

Fig. 7(a) shows the experimental set-up with a beam being tested whilc Fig. 7(b) shows the rupture cross-section located at the beam mid span.

\section{Toughness}

\subsection{Evaluating toughness of beam series}

The toughness of a material $\left(U_{T}\right)$ is defined as the capacity of a material to absorb energy in the plastic domain up to rupture [13]. This parameter is difficult to

Table 3

Last parameters and beam toughness

\begin{tabular}{lccll}
\hline Beam & $\rho(\mathrm{v} / \mathrm{u})$ & $P_{\mathrm{u}}(\mathrm{kN})$ & $\delta_{\mathrm{u}}(\mathrm{mm})$ & $U_{\mathrm{T}}(\mathrm{MPa})$ \\
\hline I B45 & 0.428 & 6.3 & 14 & 0.00885 \\
$2 \mathrm{~B} 90$ & 5.0 & 14.2 & 0.00833 \\
$3 \mathrm{~B} 150$ & & 6.1 & 10.2 & 0.00906 \\
$1 \mathrm{~B} 45$ & 1.256 & 14.6 & 11.6 & 0.02114 \\
$2 \mathrm{~B} 90$ & & 15.9 & 8.9 & 0.01643 \\
$3 \mathrm{~B} 150$ & & 15.9 & 11.1 & 0.02272 \\
$4 \mathrm{BB} 60$ & & 13.9 & 10.7 & 0.01951 \\
$1 \mathrm{~B} 45$ & 1.684 & 17.9 & 8.4 & 0.0239 \\
$2 \mathrm{~B} 90$ & & 17.0 & 9.5 & 0.0232 \\
$3 \mathrm{~B} 150$ & & 11.2 & 12.8 & 0.0322 \\
\hline
\end{tabular}

(a)

(b)

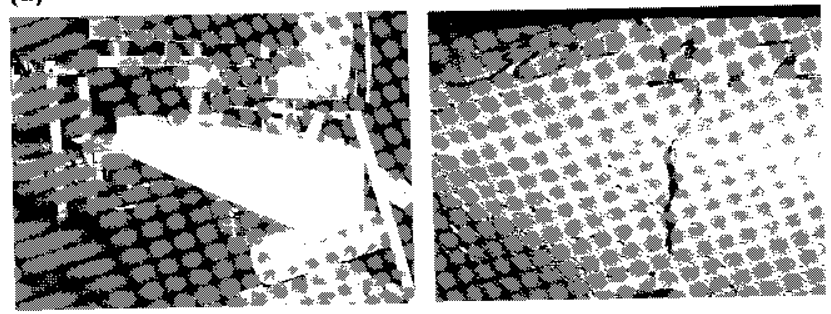

Fig. 7. (a) Experimental set-up for bending test. (b) Mid span cracked cross-section. evaluate, but a process to determine the toughness of a material consists of taking the total area $A$ limited below the stress-strain curve or the Corce -deformation curve, divided by the volume of the tested sample. This area gives an insight of the amount of energy per unit volume that the material can support up to rupture. In the scope of this work it was used as beam rupture criterion, the last measured applied load $\left(P_{\mathrm{u}}\right)$ at which an abrupt load decrease occurred (last points in Fig. 6) which coincided with the physical collapse of the beam such as seen in Fig. 7(b). The total energy $A$ was determined for the tested beams by two different procedures: (i) first determining the best polynomial equation representing the experimental data, then performing an integration to compute the area under the force-displacement curve, (ii) measuring the area under force-displacement curve. It was observed that both procedures produced very similar results (difference lower than 1\%).

In order to analyze the influence of the concrete strength on the beam toughness, it was necessary to group the beams with equal steel-bar reinforcement percentage, $\rho$. Table 3 groups the beams according to $\rho$ and shows the experimental results from the behaviour curves as well as the determined toughness values, $U_{\mathrm{T}}$.

Fig. 8 presents for cach $\rho$, the beams toughness evolution as a function of the concrete compression strength. The obscrved tendencies show that for a particular stecl-bar reinforcement percentage, toughness increases reasonably when concrete strength increases from 90 to $150 \mathrm{MPa}$.

In general, the observed tendency can be explained by the following mechanism: for a particular steel-bar rcinforcement percentage the depth of the neutral axis decreases for higher concrete strength values. This bchaviour gives rise to an increase of the last beam deflection (because the revised moment of inertia $I_{\text {cracked effecive will decrease) leading to a beam toughness }}$

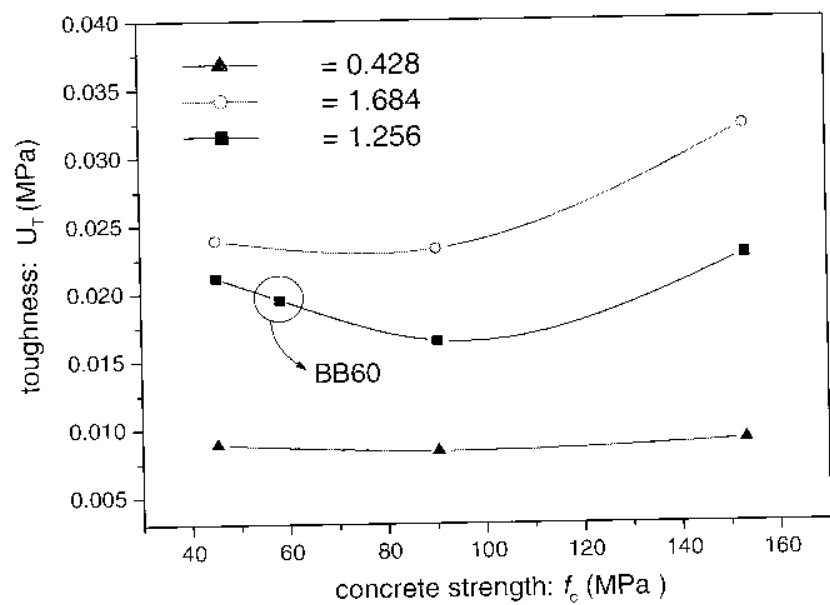

Fig. 8. Influence of concrete strenglh and steel-bar-rcinforcement percentage on beam's toughness. 

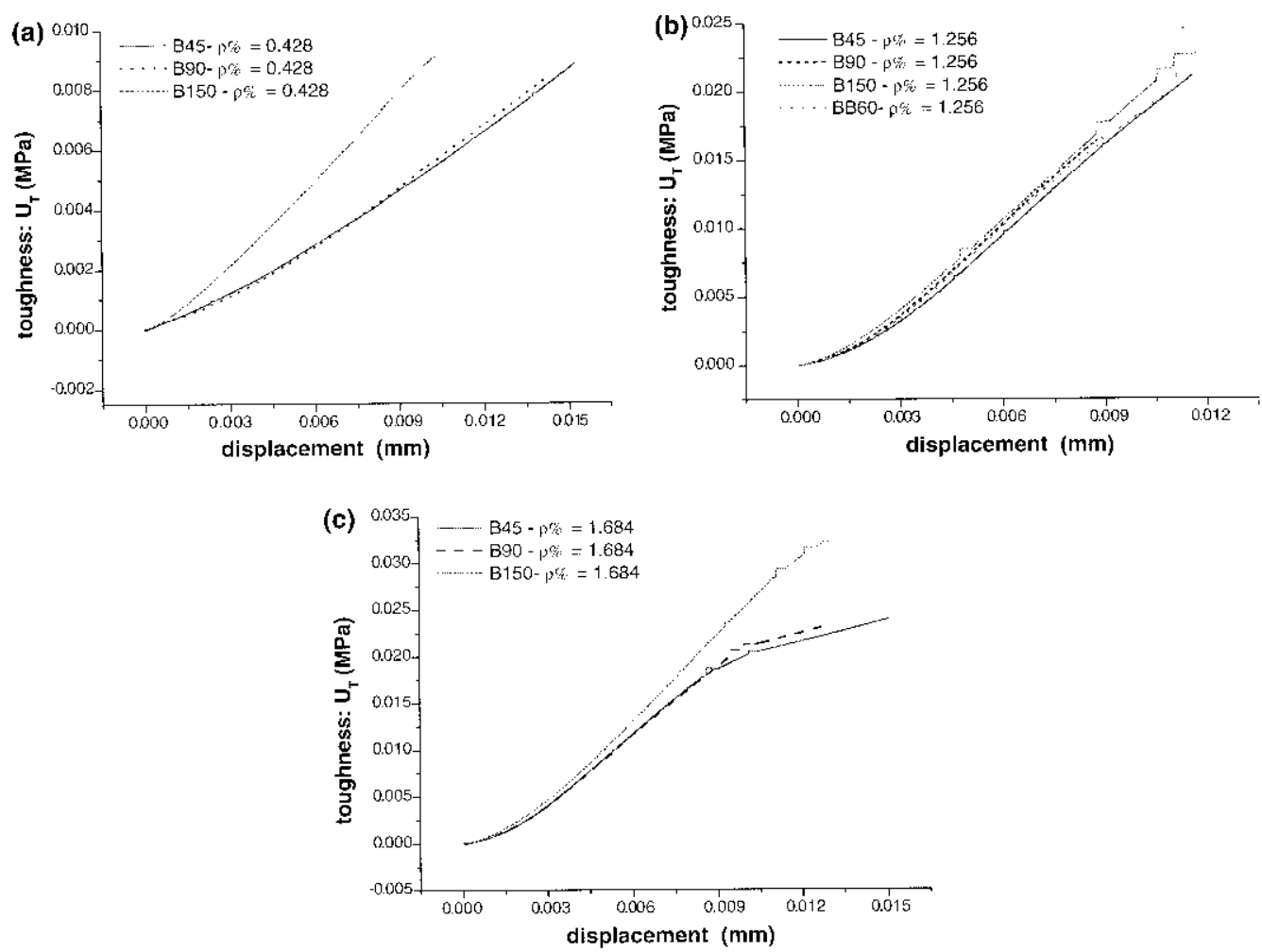

Fig. 9. Toughness as a function of the beam mid span displacement: (a) $\rho=0.428$, (b) $\rho=1.256$, (c) $\rho=1.684$.

increase. Thus, a decrease of the depth of the neutral axis appears to compensate and surpass the loss of concrete toughness for higher concrete strengths. In practice this behaviour indicates that a combination of a high performance concrete with high steel-bar-reinforcement percentage can reduce the brittle behaviour of the structure.

Fig. 9(a)-(c) shows the toughness evolution as a function of the beam mid span displacement. The same global tendency is observed showing that the better performance is achieved by the association of high performance concrete with high steel-bar-reinforcement percentage. Moreover, Fig. 9 also shows that toughness displacement curves have a parabolic shape for small values of beam deformation, which is indicative of an elastic behaviour. Meantime, for the higher deformation regime, but sufficiently far from the last points, the curves present almost a constant slope meaning a plastic behaviour of the tested element.

\subsection{The effect of steel-bar reinforcenent percentage on beam deformation}

Fig. 6 shows that for a particular concrete strength, the bcam mid span peak displacement $\left(\delta_{\mathrm{m}}\right)$ decreases for higher levels of steel-bar reinforcement. This behaviour can be explained as follows: due to an increase on the steel-bar-reinforcement percentage the depth of the neutral axis increases and as a consequence, the revised moment of inertia $I_{\text {cracked }}$ effective will increase leading to a concomitant decrease of the beam deflection. Fig. 10 plots the $\delta_{\mathrm{m}}$ as a function of $\rho$.

For increased levels of steel-bar reinforcement percentage it can be observed that for the particular casc of 45 and $90 \mathrm{MPa}$ concrete strength, $\delta_{\mathrm{m}}$ decreases strongly up to $\rho \cong 1.25 \%$ and levelling off thereafter. However, for a $150 \mathrm{MPa}$ concrete strength the beam

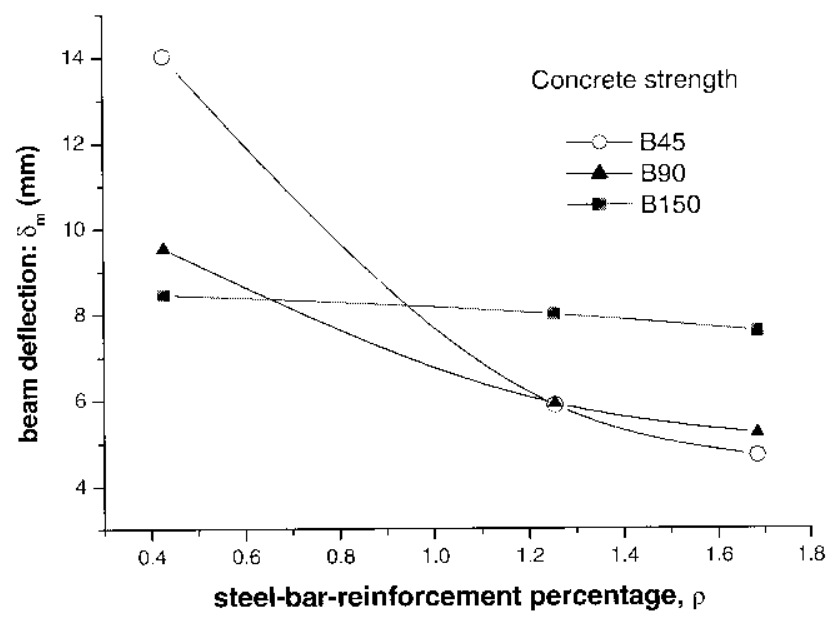

Fig. 10. Beam mid span peak displacement, $\delta_{m}$ as a function of steelbar-rcinforcement percentage. 
deflection remains almost constant for all levels of steelbar reinforcement percentage.

The experimental results can be summarized as follows:

1. HPC and high stecl-bar reinforcement percentage: B150 - 1.684 compared with conventional concrete with the cquivalent sted-bar reinforcement: B45 1.684

- The bending peak load is increased in $22 \%$.

- The beam mid span peak displacement is increased in $58 \%$.

- The bcam last displacement is increased in $52.3 \%$.

- The beam bending toughness is increased in $35 \%$.

- Reduces in 5.5\% the concrete density.

2. HPC with addition of rubber particles as partial replacement of sand (results of BB60 compared with $\mathrm{B} 90 \mathrm{for}=1.256 \%$ )

- Reduces in $33 \%$ the concrete strength.

- The bending last load is decreased in $12.6 \%$.

- The beam last displacement is increased in $17 \%$.

- The beam bending loughness is increased in $16 \%$.

- Reduces in $3.3 \%$ the concrete mass density.

\section{Conclusions}

In this research work it was observed that the most influential parameter in the loughness of the reinforced concrete beams is the steel-bar-rcinforcement percentage. The experimental results show a good agrecment between themselves indicating that in general, for constant values of concrete strength the more steel-bar reinforcement the lower the beam mid span peak displacements. This is a consequence of the increase of the revised moment of inertia due to the increase of the depth of the beam neutral axis. Experimental results also show that for a particular steel-bar-rcinforcement percentage the concrete strength influences reasonably the beams energy absorption capacity (toughness): the higher the concrete strength the higher the beam loughness. This behaviour is more pronounced for the high performance concretc B150.

Interesting practical applications may be emphasized to concrete with partial replacement of sand by rubber particles. Indeed, due to lower density it can be used in buildings as an indoor structural material, separation panels with high damping capacity to vibrations or eventually in situations where a large deformation capacity required.
Based on experimental results it is reasonable to assume that the association of a high performance concrete with a high stecl-bar reinforcement percentage will lead to an optimized technical solution in order to achieve high performance structures.

\section{Acknowledgements}

The authors thank the technical assistance from the Civil Engineering Laboratory of Minho University in moulding the concrete reinforced beams used in the experimental programme. A special thank is also addressed to all technical assistance from Electron Microscope Laboratory of Minho University which has performed the SEM micrographs.

\section{References}

[1] Application of high performance concrete. Report of the CEBFIP Working Group on High Strength/High Performance Concrete; Comite Furo-International du Beton (CEB), Lausanne, Switzerland, CEB Bulletin d'Information No. 222; Nov 1994, 66 p.

[2] Aitcin PC, Neville A. IIigh-performance concrete demystified. Concrete Int 1993:15(1):21-6.

[3] Kaplan MF. Crack propagation and the fracture of concrete. J Am Concr Inst 1961:58:591 610

[4] $\triangle$ dHoc Committee. Concrete year 2000. ACl J 1971;68(8).

[5] Baron J. Comportement du béton hydraulique: Fissurabilité el fragilitć. Rapport de Recherche LPC, No. 69; Octobre 1977.

[6] Leslie KE, Rajagopalan KS. Everard NJ. Flexural behaviour of high-strength concrete beams. ACI Struct J 1976:7349):517. 21.

[7] Tognon G, Ursella P. Coppeti G. Design and propertics of concretes with strength over $1500 \mathrm{kgf} / \mathrm{cm}^{2}$. ACI J, Proc 1980;77(3):171-8.

[8] Pastor JA, Nilson AH. Slate I\%O. Bchaviour of High-Strength Concrete Beams. Research Report 84-3, Department of Structural Enginecring. Cornell Universily, Ithaca (NY); Fev. 1984. $311 \mathrm{p}$.

[9] Shin SW, Ghosh SK, Moreno J. Flexural ductility of ultra-highstrength concrete members. ACI J Proc 1989:86(3):394 400.

[10] Ahmad SH, Barker R. Flexural bchaviour of reinlorced highstrength lightweight concrete beams. ACl Struct J Proc 1991:88(1):6977.

[1I] Lopes S, Bcrnardo L. Ductility Indices in High Performance Concrete. In: Portuguese conference in structural concrete, Lisbon. Portugal: November 2002

[12] Bowen DK, Hall CR. In: Microscopy of materials modern imaging methods using electron. X-ray and ion beams. The Macmillan Press; 1975.

[13] Polakowski NH. Ripling EY. Strength and structure of engineering materials. 2nd ed... New Jerscy: Prentice-Hall; 1966. 